\title{
Pelatihan Pembuatan Sabun Padat Herbal di Desa Cileles Kabupaten Tangerang
}

\author{
Diana Sylvia ${ }^{*}$, Dina Pratiwi ${ }^{1}$ \\ ${ }^{1}$ Sekolah Tinggi Farmasi Muhammadiyah Tangerang \\ J1 KH Syekh Nawawi No 13 Matagara Tigaraksa Tangerang 15720 Banten \\ *E-mail : didisylvia817@gmail.com
}

DOI: https://doi.org/10.21107/pangabdhi.v7i2.11800

Naskah diterima 18 Juli 2021, Revisi 27 Agustus 2021, Terbit 29 Oktober 2021

\begin{abstract}
Cooking oil is one of the main staples needed in households. Cooking oil that is no longer used can cause household waste. Unused waste oil or used cooking oil, if not managed properly, will cause environmental pollution. There are still many people who do not know how to process the remaining unused oil. Therefore, as a form of community service from the Tangerang Muhammadiyah College of Pharmacy, we tried to invite the community in the Green Palme Housing, Cileles, Tangerang Regency to be able to participate in processing used cooking oil waste so that it can be used as a useful product, namely soap making. The method used in this activity is to provide training on recycling used cooking oil by adding lemongrass essential oil to make herbal-based bath soap. Community service broadly includes 3 activities, namely data collection of participants, delivery of material by lecturers, and mentoring of soap making practices by lecturers of STF Muhammadiyah Tangerang. This training activity is expected to open up opportunities for entrepreneurship, encourage industrial houses, assist in packaging and product marketing to the community, to improve the living standards of the communities around those affected by PPKM, create jobs, and make people's lives better.
\end{abstract}

Key Words : waste, cooking oil, herbal soap, community services

\section{PENDAHULUAN}

Bertambahnya pertumbuhan jumlah penduduk saat ini, serta perkembangan industri, restoran, dan usaha fast food menyebabkan sisa minyak goreng bekas dalam jumlah yang cukup banyak. Minyak goreng bekas ini jika dipakai secara terus menerus, dapat menimbulkan penyakit dan menyebabkan tubuh kurang sehat dan stamina menurun. Jika minyak goreng bekas tersebut dibuang sangatlah tidak efisien, hal tersebut dapat mencemari lingkungan. Maka dari itu minyak goreng bekas dapat didaur ulang, salah satunya dengan menjadikan produk berbasis minyak seperti sabun cair maupun sabun padat. Minyak goreng yang digunakan pada masyarakat pada umumnya adalah minyak yang dihasilkan dari tanaman kelapa sawit, kemudian diolah sehingga menghasilkan minyak makan curah yang biasanya disebut oleh masyarakat awam, atau pada industri dikenal dengan nama CPO (Crude Palm Oil). (Wijaya et al., 2014 dalam Chandra et al., 2020).

Salah satu limbah rumah tangga atau usaha kuliner saat ini, yang memerlukan perhatian khusus adalah limbah minyak goreng atau biasa disebut dengan minyak goreng bekas/jelantah (waste coconut oil). Minyak goreng bekas jika tidak diolah dengan baik dapat menimbulkan pencemaran lingkungan, karena memiliki kandungan lemak yang sulit diurai (Panadare, 2015). Salah satu aplikasi teknologi ramah lingkungan yang dapat dilakukan dengan bahan dasar limbah minyak goreng bekas yaitu pengolahan menjadi sabun mandi. Sabun dibuat dari asam lemak yang terdapat dalam trigliserida dan basa $\mathrm{NaOH}$ direaksikan membentuk garam dan gliserin. Prosesnya disebut reaksi saponifikasi atau penyabunan (Ogunsuyi \& Akinnawo, 2012).

Sabun merupakan suatu produk dari reaksi penyabunan asam lemak yang berasal dari minyak nabati atau lemak hewani dengan penambahan dasar alkali. Sabun yang digunakan sebagai pembersih dapat berwujud padat (keras), lunak dan cair. Pada masa pandemi Covid-19, perlu dilakukannya usaha pencegahan terhadap virus Covid-19, salah satu pencegahannya yaitu dengan mencuci tangan menggunakan sabun. Sabun herbal merupakan sabun alami yang dibuat dengan mencampurkan ekstrak tanaman herbal. 
Menurut Adiwibowo (2020) bahwa terdapat beberapa tanaman yang dapat diaplikasikan seperti madu, daun kersen, jahe merah, lengkuas, lidah buaya, melati, pepaya, dan serai.

Khususnya di Indonesia, ketidakstabilan kondisi perekonomian akibat pandemi COVID-19 semakin dirasakan. Pendapatan masyarakat berkurang dikarenakan adanya Pemutusan Hubungan Kerja, pengurangan gaji, penurunan laba usaha, serta pembatasan mobilitas masyarakat (LIPI, 2020). Menurut Fatimah et al., (2019) menyatakan bahwa dari rangkaian kegiatan ini masyarakat mengalami peningkatan penghasilan per hari rata-rata Rp 10.000 yang didapat dari penjualan produk. Pada kegiatan pengabdian masyarakat yang dilakukan oleh Robiyanto et al., (2017) menunjukkan respon positif dari peserta yang ingin menambah wawasan mengenai pembuatan sediaan farmasi dari bahan alam. Berdasarkan uraian tersebut, maka untuk meningkatkan kesejahteraan keluarga melalui sektor perekonomian perlu dilakukannya pendampingan pembuatan sabun padat herbal di Perum Green Palme RW 01 Desa Cileles Kabupaten Tangerang Banten antara ibu-ibu PKK bersama Tim Dosen dan Mahasiswa STF Muhammadiyah Tangerang.

\section{METODE}

Kegiatan pengabdian kepada masyarakat ini dilaksanakan pada bulan April 2021. Kegiatan ini merupakan salah satu pelaksanaan dari Tri Dharma Perguruan Tinggi, yang dilakukan oleh dosen dan mahasiswa. Kegiatan pengabdian masyarakat ini, dilakukan meliputi 2 kegiatan pokok yaitu: (1) memberikan edukasi mengenai pembuatan sabun herbal dari bahan alami dan (2) melakukan praktik pembuatan sabun padat herbal.

Proses pembuatan sabun menggunakan metode panas dengan water bath sebagai medianya. Minyak kelapa sawit yang telah ditempatkan dalam beaker glass dipanaskan dengan waterbath. Masukkan asam stearat, lalu aduk hingga homogen. Kemudian masukkan larutan $\mathrm{NaOH} 30 \%$ hingga membentuk stok sabun. Setelah itu masukkan bahan pendukung lainnya yaitu, gliserin, sirup gula (gula pasir+akuades yang dicairkan terlebih dahulu), coco-DEA, $\mathrm{NaCl}$ dan etanol 96\%, kemudian aduk hingga seluruh adonan tercampur sempurna. Untuk penambahan minyak atsiri, adonan sabun diturunkan terlebih dahulu suhunya hingga mencapai $\pm 60^{\circ} \mathrm{C}$. Campuran diaduk kembali hingga minyak atsiri tercampur sempurna, kemudian tuangkan ke dalam cetakan silikon dan diamkan selama 24 jam pada suhu ruang.

Tabel 1. Formulasi Pembuatan Sabun Padat Herbal

\begin{tabular}{|l|l|c|c|}
\hline \multirow{2}{*}{ No } & \multicolumn{1}{|c|}{ Bahan } & \multicolumn{2}{c|}{ Berat (gram) } \\
\cline { 3 - 4 } & & 1 Resep & 5 Resep \\
\hline 1 & Minyak kelapa sawit & 60 & 300 \\
\hline 2 & Asam stearat & 21 & 105 \\
\hline 3 & $\mathrm{NaCl}$ & 0,6 & 3 \\
\hline 4 & $\mathrm{NaOH} \mathrm{30 \%}$ & 60,9 & 304,5 \\
\hline 5 & Etanol 96\% & 45 & 225 \\
\hline 6 & Gula Pasir & 45 & 225 \\
\hline 7 & Gliserin & 39 & 195 \\
\hline 8 & Coco-DEA & 3 & 15 \\
\hline 9 & Minyak Atsiri & 1 & 5 \\
\hline 10 & Akuades & 24,5 & 122,5 \\
\hline
\end{tabular}

Sumber : Widyasanti et al., (2016)

\section{HASIL PEMBAHASAN}

Kegiatan pelatihan ini dilaksanakan dari pagi hingga siang hari untuk memberikan kesempatan yang cukup bagi peserta untuk mempraktikkan pembuatan sabun herbal. Selama pelatihan berlangsung para peserta cukup antusias dalam mendengarkan arahan, dan mempelajari dasar pembuatan sabun serta mempraktikannya dalam pembuatan sabun herbal. Acara kemudian dilanjutkan dengan pemberian materi mengenai edukasi mengenai pembuatan sabun herbal dan langkah mencuci tangan dengan benar (Gambar $1)$.

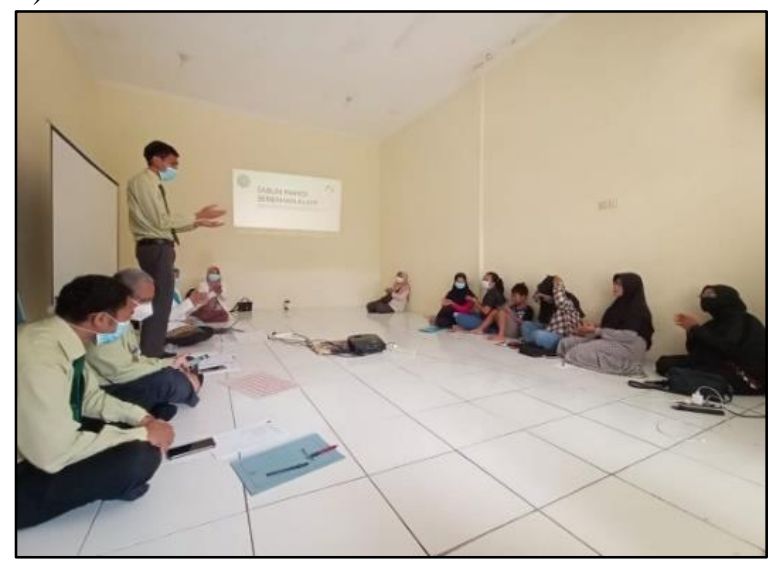

Gambar 1. Edukasi Mengenai Pembuatan Sabun Herbal

Sabun yang dibuat dalam pelatihan ini adalah sabun mandi herbal yang merupakan sediaan pembersih kulit yang tersusun dari basis sabun dan ditambahkan bahan-bahan aditif lain yang diijinkan penggunaannya sehingga berkinerja baik serta lebih menarik bagi konsumen. Basis sabun mandi yang digunakan berupa basis sabun 
konvensional yang merupakan hasil reaksi saponifikasi antara minyak atau lemak dengan larutan alkali sehingga dihasilkan garam dari asam lemak yang mempunyai sifat ampifatik.

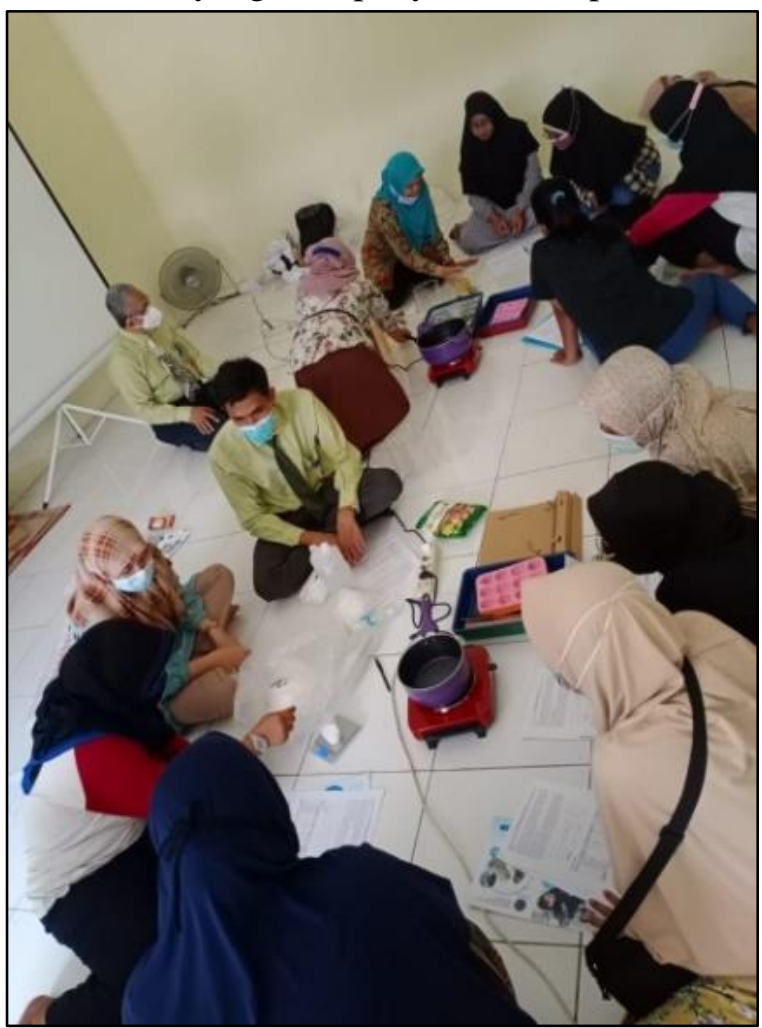

Gambar 2. Praktek Pembuatan Sabun Mandi Herbal

Proses pembuatan sabun dilakukan menggunakan metode panas dengan penangas air sebagai medianya (Gambar 2). Minyak kelapa sawit yang telah dipanaskan, ditambahkan dengan asam stearat dan larutan $\mathrm{NaOH} 30 \%$ sehingga membentuk stok sabun. Setelah itu ditambahkan bahan pendukung lainnya yaitu, gliserin, sirup gula (gula pasir+akuades yang dicairkan terlebih dahulu), coco-DEA, $\mathrm{NaCl}$, dan etanol 96\%. Pada proses pemcampuran ini perlu dilakukan pengadukan yang konstan dengan suhu $80-100^{\circ} \mathrm{C}$ hingga seluruh adonan tercampur sempurna dan berwarna transparan. Saat penambahan minyak atsiri serai, adonan sabun harus diturunkan terlebih dahulu suhunya hingga mencapai $\pm 60^{\circ} \mathrm{C}$. Setelah semua bahan tercampur sempurna, kemudian dilakukan pencetakan selama 24 jam pada suhu ruang. Hasil sabun mandi herbal minyak atsiri serai dapat dilihat pada Gambar 3 .

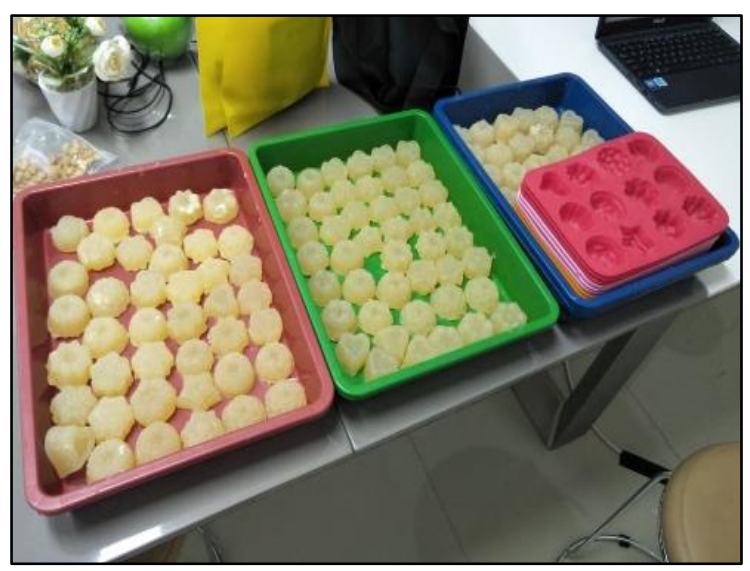

Gambar 3. Hasil Sabun Herbal Minyak Atsiri Serai

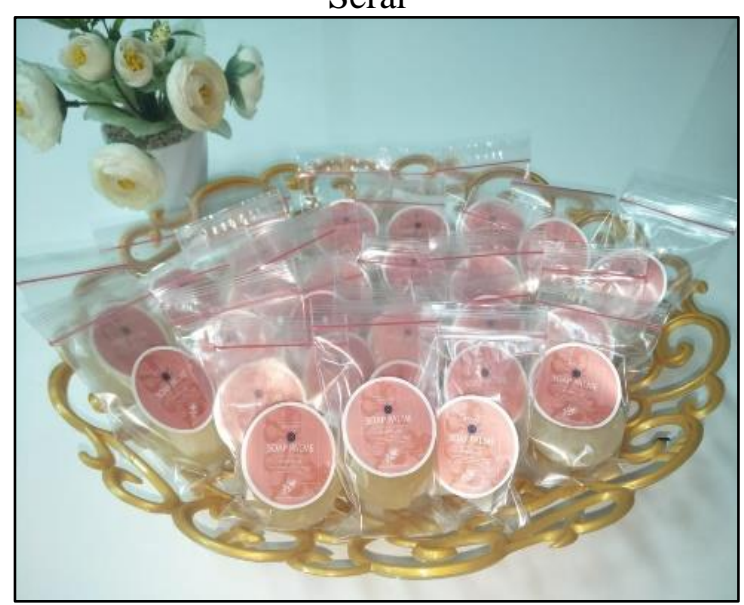

Gambar 4. Pengemasan Sabun Herbal Minyak Atsiri Serai

Produk sabun yang dihasilkan selama pelatihan dan penyuluhan tersebut transparan, berbusa, tidak panas, tidak menyebabkan kulit kering, dan tidak menimbulkan gatal-gatal. Untuk meningkatkan nilai estetika dan ekonomi dari sabun herbal yang telah dibuat, sabun tersebut dikemas dengan plastik dan diberi label seperti yang dapat dilihat pada Gambar 4. Setelah pelatihan pembuatan sabun herbal selesai, panitia segera menyebarkan kuesioner post tes untuk diisi masing-masing peserta. Hasil jawaban peserta pelatihan menunjukkan bahwa peserta dapat mengenal bahan-bahan yang digunakan dan memahami teknik pembuatan sabun herbal setelah dilakukannya pelatihan. Peserta juga merasa puas dengan narasumber dan materi yang disampaikan pada saat pelatihan karena sesuai dengan harapan peserta. 


\section{KESIMPULAN}

Secara umum kegiatan pengabdian kepada masyarakat ini dilaksanakan agar Dosen Sekolah Tinggi Farmasi Muhammadiyah Tangerang dapat melaksanakan kewajiban Tri Dharma Perguruan Tinggi serta dapat membantu masyarakat dalam meningkatkan derajat kesehatan dan kesejahteraan di masa pandemi Covid-19. Berdasarkan hasil kuesioner dari kegiatan ini, masyarakat merasa terbantu dengan bertambahnya ilmu pengetahuan mereka mengenai pembuatan sabun alami dan merasa antusias jika akan dilaksanakan kegiatan seperti ini.

\section{DAFTAR PUSTAKA}

Adiwibowo, M.T. 2020. “Aditif Sabun Mandi Berbahan Alami: Antimikroba Dan Antioksidan". Jurnal Integrasi Proses. Vol. 9, No. 1 (Juni 2020) 29 - 36.

Afrozi, A. S. et al..2017. "Pembuatan Sabun dari Limbah Minyak Jelantah Sawit dan Ekstraki Daun Serai dengan metode Semi Pendidihan, " Jurnal Ilmiah Teknik Kimia UNPAM, 1(1).

Chandra. et.al. 2020. "Pelatihan Pembuatan Daur Ulang Minyak Jelantah Berbasis Ecogreen di Rumah Singgah Yatim dan Dhuafa Kota Banjarbaru" Jurnal Abdimas Kesehatan (JAK), 2(1) .

Fatimah, S., Wiharto, Indrasari, A. 2019. Ekonomi Kreatif Melalui Pendampingan Pembuatan Sabun Cair Cuci Piring dan Pewangi Pakaian di Kabupaten Klaten

LIPI, 2020. Survei Dampak Pandemi COVID-19 terhadap Ekonomi. http://lipi.go.id/siaranpress/survei-dampakpandemi-covid-19-terhadap-ekonomi-rumahtangga-indonesia/22123. Diakses tanggal 05 April 2021.

Ogunsuyi, H. O., \& Akinnawo, C. A. (2012). "Quality Assessment of Soaps Produced from Palm Bunch Ash-Derived Alkali and Coconut Oil". Journal of Applied Sciences and Environmental Management, 16(4).

Panadare, D. C. (2015). "Applications of Waste Cooking Oil Other than Biodiesel: A Review". Iranian Journal of Chemical Engineering (IJChE), 12(3), 55-76.

Robiyanto, Sari, R., Apridamayanti, P., Untari, E.K. 2017. "Pelatihan Pembuatan Sabun Cair Lidah Buaya Pada Kelompok Aspeliya Pontianak". GERVASI, Vol. 1, No. 1, Desember 2017 ISSN: 2598-6147 (Cetak) ISSN: 2598-6155 (Online).

Widyasanti, A., Farddani, C.L., Rohdiana, D.. 2016. "Pembuatan Sabun Padat Transparan Menggunakan Minyak Kelapa Sawit (Palm Oil) dengan Penambahan Bahan Aktif Ekstrak Teh Putih (Camellia sinensis)'”. Jurnal Teknik Pertanian Lampung Vol.5, No. 3: 125-136.

Wijaya, J., Rohanah, A. dan Rindang, A.. 2014. "Pengolahan Minyak Jelantah Menjadi Sabun Batang Dengan Ekstrak Kunyit, Lidah Buaya dan Pepaya". Jurnal Rekayasa Pangan dan Keteknikan Pertanian, 2(4), hal. 139-145. 